


\title{
1-Okuma eğitimine bağlamsal bir katkı: okumanın Türkçede farklı anlamlarda kullanımı
}

\section{Selim EMİROĞLU1}

\begin{abstract}
APA: Emiroğlu, S. (2020). Okuma eğitimine bağlamsal bir katkı: okumanın Türkçede farklı anlamlarda kullanımı. RumeliDE Dil ve Edebiyat Araştırmaları Dergisi, (21), 1-22. DOI: 10.29000/rumelide.835350.
\end{abstract}

\section{$\ddot{\mathbf{O} z}$}

Bu çalışmada okumanın ilk ve temel anlamıyla birlikte Türkçede bağlamsal yönden kazandığı diğer anlamlar ortaya konulmuştur. Çalışmanın amacı, dilin dört temel becerisinden biri olan okumanın, eş zamanlı ve art zamanlı bir yaklaşımla Türkçede hangi anlamlarda kullanıldığını belirlemektir. Bu amaçla Türkçe modern ve tarihî sözlükler, ansiklopedik eserler, kitaplar, makaleler vb. yayınlar; okuma ve okumanın çekimleri (okunma, okutma), okumayla ilgili birleşik sözcük, deyim, atasözü, kalıplaşmış ifade ve cümle düzeyindeki biçimleri içermesi yönüyle taranmıştır. Ayrıca okumanın Anadolu ağızlarındaki kullanımlarına bakılmış ve Türkçede ilk zamanlardan günümüze hangi anlamlarda kullanıldığı araştırılmıştır. Nitel desende olup doküman inceleme ve içerik analizi yöntemlerinin kullanıldığı çalışmada okumanın bilinen anlamlarının dışında birçok anlamı karşılar şekilde kullanıldığı, içinde bulunduğu bağlama göre farklı anlamlar oluşturabildiği görülmüsstür. Okumanın kazandığı söz konusu anlamların bilinmesi okuma eğitimini temellendirmek bakımından yararlı olacaktır. Çalışma sonucunda eğitimcilere, araştırmacılara ve kurumlara bazı önerilerde bulunulmuştur.

Anahtar kelimeler: Türkçe, okuma, çok anlamlılık, bağlam, anlam

\section{A contextual contribution to reading education: use of reading in different meanings in Turkish}

\begin{abstract}
In this study, along with the first and basic meaning of reading, other meanings that reading gains in Turkish contextually have been revealed. The aim of the study is to determine what meanings reading - one of the four basic skills of the language - is used in Turkish with a simultaneous and diachronic approach. For this purpose, Turkish language has been scanned in terms of including modern and historical dictionaries, encyclopedic works, books, articles and similar publications; reading and conjugation of reading; compound words, idioms, proverbs, stereotypes and sentencelevel forms related to reading. In addition, the usage of reading in Anatolian dialects has been examined and the meanings of reading used in Turkish from the earliest times to today have been investigated. In this qualitative study using document review and content analysis methods, it has been observed that reading is used in a way that meets many meanings other than its known meanings, and it can create different meanings depending on the context it is in. Knowing the aforementioned meanings gained by reading will be useful to base the reading education. In consequence of the study, some suggestions have been made to educators, researchers and institutions.
\end{abstract}

Doç. Dr., İstanbul Aydın Üniversitesi, Eğitim Fakültesi, Türkçe ve Sosyal Bilimler Eğitimi Bölümü, Türkçe Eğitimi ABD (İstanbul, Türkiye), selimemiroglu@aydin.edu.tr, ORCID ID: 00oo-0003-4892-9575 [Araştırma makalesi, Makale kayıt tarihi: 01.09.2020-kabul tarihi: 20.12.2020; DOI: 10.29000/rumelide.835350]

Adres
Address

İstanbul Medeniyet University, Faculty of Education Sciences,

Turkish and Social Scinces Education, Turkish Language Teaching

Education, Cevizli Campus, Kartal-İstanbul /TURKEY

e-mail: editor@rumelide.com 
Keywords: Turkish, reading, polysemy, context, meaning

\section{Giriş}

Sözcükler genellikle birden fazla anlamı karşılar. "Hangi dilde olursa olsun, bir sözlüğü karıştıracak olursak onun içinde yer alan sözcüklerin pek çoğuna, birden fazla anlam verildiğini, bu anlamların numaralanarak açıklandığını görürüz” (Aksan, 2006: 58). Buna çok anlamlılık (polysemy) denir. Çok anlamlılık, sözcüklerin kurdukları ilişkiler sonucu gelişir. Türkçede çok anlamlı sözcüklerden biri olan okuma(k), elektronik ortamdaki Güncel Türkçe Sözlük’te 10 farklı anlamda verilmiştir. Bu kullanımlar; temel, mecaz, argo vb. anlamlar olarak belirtilmiştir.

Doğaldır ki dildeki sözcüklerin bütün anlam ve kullanımları sözlüklere yansımaz. Sözcükler; kullanıma ve bağlama göre değişen anlamlara sahiptir. Ancak dilde sözcüklerin uzun zamandan beri kalıplaşmış, bilinen ortak anlam ve kullanımları vardır. Türkçede okuma, sözlükteki bu 10 anlamın dışında birçok anlamı karşılamakta ve birçok anlamda kullanılmaktadır.

Bağlam olmadan anlama ulaşılmaz. Bu nedenle çalışmada okumanın, içinde yer aldığı cümle, ortam, metin vb. dikkate alınarak kazandığı anlamlar araştırılmıştır. Okumayı sadece sözlükte verilen anlamlarla değil, asıl anlamıyla bir şekilde ilişkili kullanımlarıyla incelemek uygun olacaktır. Böyle olursa anlam bulanıklığının da önüne geçilir. "Ancak içinde geçtiği metin ve bağlama, konuya bakılınca kavram kolayca aydınlanır, bir anlaşılma zorluğu kalmaz” (Aksan, 2006: 72).

Çalışmanın merkezinde morfolojik ve etimolojik bir yön bulunmasa da okuma sözcüğünün köken ve yapı bilgisini baştan ortaya koymak gerekir. Okuma, Türkçe bir sözcüktür ve yay ile atılan bir savaş gereci olan "ok" sözcüğünden türemiştir (ok+1-:okımak). "İlk dönemlerde ve hatta bugün hâlâ Anadolu'nun çeşitli yerlerinde 'çağırmak, davet etmek' manasına gelen bu fiilin daha sonra 'okumak' anlamına gelmesini, 'okun ucuna birtakım işaretler koymak suretiyle haber yollamak' manasından çıkarabiliriz” (Tekin, 2001: 29). Okumanın ok ile ilişkisini diğer kaynaklar da benzer çözümlemeyle (Gülensoy, 2007: 619, Çağbayır, 2007: 3601) açılamıştır.

Okun ucuna konulan işaretler, oka sarılan kâğıttaki yazılar, atılan okun üzerindeki mesajla haber vermek, iki ok arasında bulunup dürülebilen ferman niteliğindeki anlaşma araçları, birbirlerine ok vererek kurulan iletişim vb. "ok"la oluşturulan her türlü anlaşma yolu okuma eylemine anlam katmıştır. Anadolu ağızlarında kullanılan "oku vermek” 'düğüne çağrı için hediye vermek, davetiye vermek' (Çağbayır, 4. Cilt, 2007: 3600) anlamındadır ve bu bilgiyi destekler. Sözcüğün emir kipi kullanımı (oku!) da, isim olarak (oku), Anadolu ağızlarında 'davetiye', 'armağan' gibi anlamlarda kullanılır. Nasıl ki yazar, kurguladığı veya planladığı metin aracılığıyla okurlara sesleniyorsa eski dönemlerde insanlar da "ok"u bir kalemden çok kâğıt gibi kullanarak okun üzerindeki veya oka iliştirilen parçaların (kâğıt, deri vb.) üzerindeki işaret ve yazılarla iletişim kurup anlaşmıştır.

Yapılan literatür taramasında okumanın Türkçede kazandığı anlamları inceleyip sinıflandıran herhangi bir çalışmaya rastlanmamıştır.

\section{1. Çalışmanın amacı}

Çalışmanın amacı, okumanın Türkçede bağlama göre hangi anlamlarda kullanıldığını ortaya koymaktır. Bu amaçla okuma sözcüğü ve okumanın çekimlerinin yer aldığı sözcük, sözcük grupları ile 
cümle biçimindeki kalıplaşmış yapılar incelemeye alınmış; okumanın art zamanlı ve eş zamanlı bir incelemeyle Türkçede hangi anlamlarda kullanıldı̆̆ı belirlenmiştir.

\section{2. Çalışmanın önemi}

Çalışma, okumanın Türkçede farklı anlamlardaki kullanımlarını ortaya koymak, okuma eğitimine bağlamsal açıdan katkı sunmak yönüyle önem taşımaktadır.

\section{3. Çalışmanın yöntemi}

Çalışma nitel desende olup doküman inceleme yöntemiyle oluşturulmuştur. Okumanın kazandığı anlamlar bütünleştirilip kategoriler oluşturulurken içerik analizine başvurulmuştur. "Nitel araştırma yaklaşımı bir olgu, olay ya da durum hakkında daha derin ve bütünsel bilgi sağlaması amacıyla kullanılır" (Cresswell, 2003; Akt. Sevim ve Şeref, 2015: 367). "Doküman incelemesi, araştırılması hedeflenen olgu ve olgular hakkında bilgi içeren, yazıll, görsel materyallerin analizini kapsar (Yıldırım ve Şimşek, 2008: 187-188). İçerik analizi ise "Belirli kurallara dayalı kodlamalarla bir metnin bazı sözcüklerinin daha küçük kategorileri ile özetlendiği sistematik, yinelenebilir bir tekniği ifade etmektedir" (Büyüköztürk vd., 2012: 240). Bu çalışmada içerik analizi, toplanan verilerin sınıflandırılmasında kullanılmıştır. Araştırma, okumanın etimolojisinden çok anlamına dönük bir inceleme niteliğinde olup semantik bir yaklaşımla oluşturulmuştur.

\subsection{Sinurlılıklar}

Çalışmada okumanın edilgen ve ettirgen (okunma, okutma) biçimleri de incelenmiştir. Tekrarı önlemek amacıyla, okumanın içinde yer aldığı ifadenin basit sözcük, birleşik sözcük, deyim, terim, atasözü vb. oluşuna; karşıladığı anlam ve kullanımına bakılarak ifade sadece bir kategoride incelemeye ve değerlendirmeye alınmış, farklı kaynaklarda geçen aynı ya da benzer ifadeler çalışmaya dâhil edilmemiştir.

\subsection{Problem durumu}

Çalışmanın problem cümlesi şu şekildedir: “Okuma, Türkçede hangi anlamlarda kullanılmaktadır?”

\section{Bulgular ve tartışma}

Bu bölümde, başta Güncel Türkçe Sözlük ve TDK’nin elektronik ortamdaki diğer sözlükleri (atasözleri ve deyimler sözlüğü, tarama sözlüğü, derleme sözlüğü) olmak üzere Türkçedeki birçok tarihî ve modern sözlüğün, kitapların, ansiklopedik eserlerin, bilimsel çalışmaların taranmasıyla, içinde okuma (okunma, okutma) sözcüğünün bulunduğu sözcük, sözcük grubu ve cümle yapısındaki ifadelerin, Güncel Türkçe Sözlük’teki “okumak” sözcüğünün anlam sıralamasına ve okumanın tespit edilen diğer anlamlarına göre sınıflandırılması yer almaktadır.

\subsection{Okumanın ilk ve temel anlamı}

30 kadar harf ve 15 civarında noktalama işaretinin çeşitli kombinasyonlarıyla oluşturulan metinlerin anlaşılmak amacıyla çözümlenmesi denilebilecek okuma, bir anlama becerisidir. "Okuma, bir dizi yazılı simgenin bilgiye dönüştürüldüğü çözümlemeli, bireşimsel süreçtir (İmer, Kocaman ve Özsoy, 2011: 195).

\footnotetext{
Adres $\mid$ Address

İstanbul Medeniyet Üniversitesi, Eğitim Bilimleri Fakültesi, Türkçe İstanbul Medeniyet University, Faculty of Education Sciences, ve Sosyal Bilimler Eğitimi Bölümü, Türkce Eğitimi ABD Cevizli Turkish and Social Scinces Education, Turkish Language Teaching Kampüsü, Kartal-İstanbul/TÜRKIYE $\quad$ Education, Cevizli Campus, Kartal-İstanbul /TURKEY e-posta: editor@rumelide.com 1 e-mail: editor@rumelide.com
} 
Okumak, Güncel Türkçe Sözlük’te 1. anlamıyla "bir yazıyı meydana getiren harf ve işaretlere bakıp bunları çözümlemek veya seslendirmek" biçiminde verilir. "Yazı dilinin anlamlı olarak çözümlenmesi ve yorumlanması" (Harris ve Sipay, 1990: 10) olan okuma, metinde iletilenleri önce herkesin bildiği yollardan fark etmek, sonrasında sonsuz bilinmeyenlere kapı açan algoritmalar oluşturup anlam derinliklerine ulaşmaktır. "Her okuyucu zihninde var olan şemalara, ön öğrenmelerine göre okuma sırasında metinden farklı bir anlam geliştirebilir ve yorum çıkarabilir” (Karatay, 2014: 80).

Okumanın ilk ve temel anlamı basılı malzemeyle ilişkilidir. Okuma, "Basılı sözcükleri kavrama ve yorumlamaya dayanan zihinsel bir etkinliktir" (Özdemir, 1991: 13). Binbaşığlu da (1993: 15) okumayı benzer şekilde tanımlar: "Okuma, çok kısa olarak, basılı bir sayfadaki yazılan düşünceyi anlamak yahut bir sayfadan anlam çlkarmaktır."

Okumanın fizyolojik ve psikolojik ya da psikomotor ve bilişsel özellikleri, okuma tanımlarında öne çlkar. Demirel'e (1999: 59) göre okuma "Bilişsel davranışlarla psikomotor becerilerin ortak çalışmasıyla, yazılı sembollerden anlam çıkarma etkinliğidir.” Yıldız’a (2010: 115) göre okuma etkinliği, "Yazıdaki duygu ve düşüncelerin kavranması, çözümlenmesi ve değerlendirilmesi gibi fizyolojik, zihinsel ve ruhsal yönleri bulunan karmaşı bir süreçtir." Özbay ise okumayı "Görme ve seslendirme yönüyle fiziksel, kavrama yoluyla zihinsel bir süreç” (Özbay, 2011: 5) olarak tanımlar.

Karıştırılmış harfler üzerinde işlem yapmak denilebilecek okumada genellikle durağan kod ve semboller, dil göstergeleri vardır ve okuyucu bunları anlamlandırır. Okuma, metindeki dağınık anlamı derleyip toparlama, anlamı zihinsel yönden inşa etme sürecidir. Video gibi akış halindeki hareketli gösterimleri anlamlandırmak, bir başka beceri olan dinleme/izleme kapsamındadır. Ancak günümüzde hareketli resim denilen "gifleri” çözümlemek ise bir anlamda yarı okuma yarı izlemedir.

Bilinen temel anlamının dışında, bağlama göre kazandığı mecaz anlamlarla okuma; kod, harf veya karakter çözümlemenin dışında çok farklı anlamları ifade eder hale gelmiştir. Okuma denilince anlama, deşifre etme, açığa çıarma, kod çözme, bağ kurma, ilişkilendirme, değerlendirme, kişi, durum ve olguları analiz etme vb. anlaşılmaktadır.

Teknolojinin gelişmesiyle birlikte okumanın tanımında önemli değişiklikler olmuştur. Günümüzde okuma nesnesinin artık sadece yazılı kodlar olmadığı, okumanın yazılı ve basılı şeyleri algılamaktan çok, dikkatimize sunulan her türlü bilgi, durum veya olguyu kavramak biçiminde yeni bir anlam kazandığı görülür. "Günümüzde ise okuma yazılı ve yazısız kaynaklar, okuyucu ve çevresel unsurların etkileşimi sonucu oluşan anlam kurma süreci olarak tanımlanmaktadır” (Akyol, 2003: 14).

Okumada ön bilgi ve deneyim önemlidir. Okuma, bir anlamda, yazılı karakterler veya görseller üzerinde ön öğrenmeleri kullanmaktır. Yapılandırmacı ve bilişsel yaklaşımın ortaya koyduğu gibi, okuma, okurun ön bilgileriyle, okuduğu metindeki bilgileri sentezleyerek yeni anlamlara ulaşmasıdır. Bu bakımdan okurun özellikleri metnin özelliklerinden daha fazla önem taşır. "Okunan metnin tam ve doğru anlaşılması, okuyanın birikimine bağlıdır. Hiçbir yazılı kaynak kendini ifade edici değildir. Okuyucu ön bilgilerini kullanarak onu çözmeye çalışır” (Arıcı, 2012: 20).

Dilin dört temel becerisi vardır. Bunlar; dinleme, konuşma, okuma ve yazmadır. Bu becerilerden okuma ve dinleme, anlama becerisidir. "Okuma ve dinleme, anlama alanına ait iki beceridir. Bu iki beceri, dışarıdan gelen uyarıcıların anlamlandırılması bakımından benzerlik göstermektedir" (Emiroğlu ve Pınar, 2013: 776). Hem dinleme hem de okuma, tahminlerin harekete geçtiği bir yapı 
çözümlemesidir "Bu durumda anlamanın oluşabilmesi için okuyucu ya da dinleyici tarafından cümlenin parçalara ayrılması, söylem bütünlüğü içinde ne denmek istendiğinin anlaşılması, söylemle ilgili bir yapı oluşturulması ve bunun daha önceden bilinen arka plan bilgileriyle bağdaştırılması gerekir" (Razı, 2007: 35).

Okuma, anlamanın bir parçası, bir aracıdır. Okumanın göstergesi ve nihai hedefi anlamadır. Okuma, metinde veya görselde ne iletildiğini kavrama ve buna uygun tepkiler geliştirmedir. "Okuduğunu anlama sadece, okunan metindeki bilinmeyen sözcükleri anlamlandırmak, onların sözlükteki anlamını bulmak değildir. Anlamak, okunanı kavramaktır. Kavramanın belirtisi ise metni değerlendirebilmek, ondaki bilgiyi kendine mâl edecek kadar yorumlayabilmektir" (Karatay, 2014: 2). Anlama zihinseldir ve içinde neden sonuç, çıkarım, yorum, analiz, sentez, değerlendirme gibi düşünme süreçlerini barındırır. Bu süreçleri işletebilmek için okuma materyalleri kullanılır. Okumanın anlama becerisi olduğunu, Türkçedeki "tersinden okuma” ifadesi de netleştirir. Tersinden okuma, 'yanlış anlama' demektir.

Yazının icadıyla okumanın başladığı bilinse de, görsel okuma dikkate alındığında, okumanın, insanlığın dinleme ve konuşmadan sonra kullandığı 3. dil becerisi olduğu söylenebilir. Yazılı dilin anlaşılması, yazmanın ve yazarlı̆̆ın sermayesi olan okuma, doğal olarak, yazıyla ilişkilidir. Yazının varlığı, okumanın ilk ve temel anlamını daima yaşatacaktır.

Okumanın, basılı ve yazılı ürünleri okuma, çözümleme anlamı aynı zamanda okumaya değer verme, kararlı ve bilinçli okuma, okumayı alışkanlık haline getirme, kişinin okuyarak kendini geliştirmesi vb. anlamlarını da çağrıştırır. Güncel Türkçe Sözlük'ün dışındaki kaynaklarda okumanın ilk ve temel anlamına ilişkin Türkçe sözler, deyim ve atasözleri bulunur. Bu sözler, aşağıda açılamalarıyla verilmiştir:

TDK'nin çevrim içi deyim ve atasözleri sözlüğünde yer alan “içinden okumak” deyimi ilk anlamıyla 'ses çıkarmadan okumak' açıklamasıyla verilmiştir. Özellikle belirli bir yaş ve sınıftan (Uzmanlar, 4. sınıf ve sonrası olarak belirtmiştir.) sonra çocukların sessiz okumaya yönlendirildiği bilinir. Okullarda, çocukların bu tür bir okumayı daha iyi anlaması için sessiz okuma, "içinden okuma" olarak belirtilir.

İlkokuldan başlayarak münazaralarda tartışma konusu olarak da kullanılan "Çok yaşayan (okuyan) bilmez, çok gezen bilir.” atasözü (Aksoy, 1971: 104), çok gezen ve birçok şey gören kimselerin, okumayla vakit geçirenlere göre daha bilgili olacaklarını vurgulamaktadır. Okumanın gerçek anlamıyla ilgili bu söz, okumayla gezip görmeyi karşı karşıya getirir. Bu tartışma konusunda okumanın ilk ve temel anlamı kullanılır.

Akyalçın'ın (2012: 168) Türk atasözlerini topladığı çalışmasında "Âdemin hayvaniyeti yemekle, insaniyeti okumakla kaimdir.” sözü yer alır. Bu söz, ‘İnsanlar yalnız yemek için yaşadıklarında hayvanlardan bir farkları kalmaz. Ancak okuyan, fikir üreten, kimi şeylere kafa yoran ve çözüm arayan kişiler gerçek insanlardır.' açılklamasıyla verilmiştir. İnsan olmanın gereği olan okumanın bir ihtiyaç olduğu düşünülebilir.

TDK’nin deyim ve atasözleri sözlüğünde geçen bir başka deyim "su gibi bilmek” (okumak)'tir. Bu söz, 'yanlışsız bilmek veya okumak' anlamına gelir. Özellikle yanlışsız, akıcı ve hakkını vererek okuma; okumanın ilk ve temel anlamın belirtir. Deyim olarak belirtilen "yüzünden okumak" ise ilk anlamıyla

\footnotetext{
Adres $\mid$ Address

İstanbul Medeniyet Üniversitesi, Eğitim Bilimleri Fakültesi, Türkçe İstanbul Medeniyet University, Faculty of Education Sciences, ve Sosyal Bilimler Eğitimi Bölümü, Türkce Eğitimi ABD Cevizli Turkish and Social Scinces Education, Turkish Language Teaching Kampüsü, Kartal-İstanbul/TÜRKIYE $\quad$ Education, Cevizli Campus, Kartal-İstanbul /TURKEY e-posta: editor@rumelide.com 1 e-mail: editor@rumelide.com
} 
‘ezbere değil, yazılmış kâğıttan okumak’ biçiminde kaydedilmiştir. Bu deyim de okumanın, matbu ürünleri okuma anlamını yansitır.

Ömer Asım Aksoy’un Bölge Ağızlarında Atasözleri ve Deyimler adlı derlemesinde Iğdır ve Kars bölgesinde kullanıldığı kaydedilmiş "Her okuyan Molla Penah olmaz.” (Aksoy, 2004: 136) sözü, Molla Penah isimli Azeri sahası divan şairine bir göndermedir. Bu söz, aynı zamanda, okumanın ilk ve temel anlamını, yani kitap ve yayınları okumayı, bunlarla kişinin kendini geliştirmesini işaret etmektedir.

Okumanın sözlükteki ilk anlamı ve bu anlamı destekleyen deyim ve atasözleri; okuma eyleminin hala ağırlıklı olarak matbu eserlerin okunmasını kapsadığını, okunan kitaplar üzerinde düşünülmesi gerektiğini, okumayı bir ihtiyaca dönüştürmeyi, okumanın kişisel gelişim için önemini, kurallarına uygun okumayı, okumanın üstünlügünü vb. ortaya koymaktadır.

\subsection{Belirli türlerde metinler okuma}

Türkçe derslerinde kullanılan temel materyal metindir. Okuma materyali veya okuma parçası denince akla yazılı şeyler yani metin gelir. Bir metinden yola çıkarak etkinlikler düzenlenir ve metin parçalanarak dil becerileri açığa çıkarılır. Bu süreçte etkinliklerin ardına gizlenmiş kazanımlara ulaşmak hedeflenir. Ancak günümüzde dil eğitiminde temel materyalin metin olduğunu söylemek uygun olmayabilir. Örneğin, derse getirilen bir kısa film, bir metin gibi etkinleştirilerek etkinliklere konu olabilir ve kısa filmin çeşitli bileşenleri açllp genişletilerek sözcük öğretimi, dil, dil becerileri, dil bilgisi ve metin bilgisine dair eğitimler gerçekleştirilebilir.

Okumanın; belirli türlerde metinler okumak, bu metinler aracılığıyla bilgi edinmek, eğlenmek, zevk almak, araştırmak gibi bir anlamı vardır. Güncel Türkçe Sözlük’te okumanın 2. anlamı "yazılmış bir metnin iletmek istediği şeyleri öğrenmek: Gazete bile okumak istemiyorum.” açıklaması ve örneğiyle verilmiştir. Açıklama, belirli türdeki metinleri okumak ve onlar sayesinde çeşitli bilgilere ulaşmak biçiminde bir bilgiyle genişletilmelidir.

Güncel Türkçe Sözlük'teki bu anlam roman okumak, makale okumak gibi belirli türlerde yapılan okuma ve çalışmalarla da ifade edilebilir. Burada kast edilen anlam, çeşitli metinlerdeki bilgiye ulaşmak, bu şekilde bazı şeyleri öğrenmektir. Okuma eylemi bu süreçte bilgi almanın aracı; bir beceri olmaktan öte, öğrenme veya zevk alma isteğidir. Ancak bu anlamın, okumanın ilk ve temel anlamından uzaklaşmadığı da anlaşılmaktadır.

Belirli türlerde metinler okuma anlamını, okumanın 'bir eser üzerinde yoğunlaşma', 'metni inceleme' ve hatta 'ders çalışma' anlamlarıyla da ilişkilendirmek mümkündür.

\subsection{Okumak-öğrenim görmek}

Okumanın, bir diğer anlamı formal eğitimle ilişkilidir. "Okumak, bir konuyu öğrenmek için okulda, bir öğretmenin yanında veya yazılı şeyler üzerinde çalışmak, öğrenim görmek” anlamıyla da kullanılır. Okumanın eğitim öğretimle ilgili bu anlamı, Güncel Türkçe Sözlük’te 3. sıradadır.

Okuma, genel olarak, okullarda yapılır ve okul denilen kurumların varlığı, öğrenim görmeye böyle bir anlam verilmesini sağlar. "Bu kelimenin 'tahsil etmek, öğrenim görmek' gibi diğer anlamlarını ise daha sonraki müesseseleşme dönemlerinde kazandığını söyleyebiliriz (Zal, 2007: 78). Türkçedeki okul sözcüğü okumayı çağrıştırır. "Mektep, oku- fiilinin mekânıdır ve mektep için karşlık arandığında -bu 
karşlık, uydurma da olsa doğru bir türetme de olsa- akla ilk olarak oku-, öğren-, yaz-, bil- gibi aynı kavram alanından kelimeler gelecektir (Balyemez, 2017: 139).

Okumanın öğrenim görmek anlamında kullanılması uygundur. Çünkü dilin dört becerisi içinde en fazla okumaya yatırım yapılır. Eskilerin tahsil dedikleri bu süreç, okulda ve okul dışında okumalarda bulunmak, belirli öğretim programları ve planlara bağlı olarak yayınları, ders kitaplarını okumak ve takip etmek, akademik veya mesleki kariyere katkı sağlayacak okumalar yapmaktır. Bu bağlamda okumanın, eğitim öğretimin temelini oluşturduğu, okunup öğrenilmesi gereken birçok basılı malzemenin ancak okumayla anlam ve değer kazanacağı anlaşılmaktadır.

Öğrenmenin merkezinde okuma becerisi vardır. Okuma olmadan eğitim öğretim eksik kalır. Öğrenmek için ihtiyaç duyulan bilgi, kitaplardadır. Kitaplardaki bu bilgiyi çekip almak için öncelikle kurallarına uygun ve stratejik okumalara ihtiyaç vardır. Öğrenimde diğer dil becerilerinin etkileri düşünüldüğünde bu süreçte dersleri dinleme, insanları dinleme, sesleri ve videoları dinleme/izleme de önemli bir yer tutar ancak kitaplar ve öğretim programları söz konusu olduğundan okuma öne çıkar. Yine konuşma ile yazma gibi anlatım becerileri de tahsil sürecinde kendini gösterir. Fakat bunlar da çoğunlukla okumayla beslendiğinden öğrenim görme sürecinin okumayla ilişkilendirilmesi doğru olacaktır. Eskiden öğrenim görmek yerine "okumuşluk" denilirdi ki, bu aslında okuma eyleminin öğrenim görmek demek olduğuna açıklık kazandırır.

Meslek sahibi olmak, kendini geliştirmek, eğitim öğretim basamaklarında ilerlemek, kariyer yapmak, uzmanlaşmak, eksikleri gidermek vb. amaçlarla yapılan okuma, bir dil becerisi olmaktan uzaklaşarak eğitim öğretim anlamını kazanır. Öğrenim hayatını karşılayan "Nerede okuyorsun, ne okuyorsun?” türündeki sorular, okumanın bu anlamını netleştirir.

Okumanın, Güncel Türkçe Sözlük’te verilen öğrenim görme, tahsil anlamı; incelenen diğer yayınlarda da görülür. Saraçbaşı ve Minnetoğlu'nun sözlüğünde şu söz, atasözü olarak kayıtlıdır: "Geçinmeyene dokuz koca, okumayana dokuz hoca az gelir.” (Saraçbaşı ve Minnetoğlu, 1978: 271). Söz konusu atasözü okuma, tahsil görme, kariyer basamaklarında ilerleme süreçlerinin öncelikle kişinin kendisinde, özünde olan bir yeterlik, motivasyon ve arzu olduğunu ortaya koymaktadır.

Bir başka kaynakta yer alan "Benim oğlum bina okur, döner döner yine okur." deyimi şöyle açıklanmıştır: "Eski eğitim sistemimizde birçok kez tekrar edilerek anlaşılan Arapça yapılarla ilgili olan bu deyim, tekrardan kurtulamayan ve işin içinden çıkamayan çocukları alaycı bir şekilde ifade etmek için kullanılır. Buradan hareketle de bir işi çokça tekrar etmesine rağmen başarı gösteremeyen, ilerleme kaydedemeyen kişiler bu sözle eleştirilir" (Ayverdi, 2011: 132). Buradaki anlam, okumanın ilk ve temel anlamını işaret ettiği gibi, okul ortamında yapılan alıştırma ve çalışmaları da belirtmektedir. Ancak sözün öncelikle mecaz anlamda kullanıldığı bilinmelidir.

İncelenen çeşitli yayınlardaki bazı deyim ve atasözlerinde, okumanın kitap okuma anlamı ile öğrenim görme anlamının iç içe geçtiği görülmüştür. Bu bağlamda Ömer Asım Aksoy'un bölge ağızlarıyla ilgili eserinde şu atasözü ve deyimler yer alır:

"Oku oğlum oku, yaz; okumazsan sana derler baba ördek, baba kaz.” (Suşehri-Sivas/Aksoy, 2004: 175)

“Okumadan hoca, yazmadan kâtip.” (Sivrihisar-Eskişehir/Aksoy, 2004: 368)

"Okumak istersen eliften başla, üşümeyim dersen şehirde kışla, geçineyim dersen iddiayı boşla." (Niğde/Aksoy, 2004: 74)

\footnotetext{
Adres $\mid$ Address

İstanbul Medeniyet Üniversitesi, Eğitim Bilimleri Fakültesi, Türkçe İstanbul Medeniyet University, Faculty of Education Sciences, ve Sosyal Bilimler Eğitimi Bölümü, Türkce Eğitimi ABD Cevizli Turkish and Social Scinces Education, Turkish Language Teaching Kampüsü, Kartal-İstanbul/TÜRKIYE $\quad$ Education, Cevizli Campus, Kartal-İstanbul /TURKEY e-posta: editor@rumelide.com 1 e-mail: editor@rumelide.com
} 
“Hoca okuttuğu kadar, çoban güttüğü kadar.” (Taşova-Amasya/Aksoy, 2004: 139)

“Keten gömlek olmaz dokutmayınca, evlat âlim olmaz okutmayınca.” (Van/Aksoy, 2004: 157)

“Çocuğu babanın akçasıyla ananın bohçası okutur.” (Niğde/Aksoy, 2004: 35)

Okumanın, daha çok, okutma sözcüğüyle ifadesini bulan bu anlamı, okuma eyleminin öğrenim görmenin temelini oluşturduğunu yansıtır. Bu sözler, kültürümüzde okumaya, öğrenim görmeye verilen değeri ortaya koyması bakımından da önemlidir.

\subsection{Okumanın konuşma ve sesletimle ilişkisi}

Okumanın temel anlamı, daha çok, sessiz okumaya gönderme yapar. Oysa okumanın bir de sesli okuma, sesletim boyutu bulunur. Okumanın Güncel Türkçe Sözlük'teki 4. anlamı 'sesli olarak söylemek’tir. Örnek cümle ise şu şekildedir: "Salon boşalmaya başladı, biz şiirler okuyup dinliyoruz."

Okumanın özünde şifrelenmiş yapıları çözmek veya bunları seslendirmek vardır. Demirel (1999: 64) sesli okumayı, "Gözle algılanıp zihinle kavranan kelimelerin ve kelime kümelerinin konuşma organlarının yardımı ile söylenmesi” olarak tanımlar. Dört dil becerisinin etkileşim içinde olduğu sesli okumada kişi, onu dinleyen dinleyici kitlesinin anlayabileceği bir şekilde, metnin özelliklerine bağlı olarak, diksiyon unsurlarını da dikkate alan bir okuma gerçekleştirir. Sesli okumada yazılı metnin yazma, dinleme eyleminin dinleme, metni sesletmenin okuma ve sesletim becerisinin konuşmayla ilişkisi vardır.

Güncel Türkçe Sözlük’teki anlam, sesli okuma ve sesletimi birleştiren bir açıklamadır. Bu durumda, sesli okumanın, yerine göre, konuşma olduğu söylenebilir. Metne bağlı okumalar, prompterdan (elektronik suflör) yapılan okumalar, demeçler, basın açıklamaları, nutuklar, duyurular vb. birer konuşmadır. Ancak bu türden konuşmaların hazırlıklı konuşma sayıldığı, özellikle kritik ve hataya yer olmayan açıklamalarda kullanıldığı da bilinmektedir.

Okuma, bir anlama becerisidir ancak bazı durumlarda okumanın anlatma becerisine dönüştüğü görülür. Sesli okumalar bunun örneğidir. Okumanın fiziksel yönü olan seslendirme; anlatma, söyleme ve konuşma ile kesişir. "Bana masal okuma!", "Bu harf böyle okunur.”, "Bana ne okuyorsun?” ya da "kısa heceyi uzun okuma" vb. kullanımlarda okumanın söylemek anlamına geldiği, konuşmayla eşdeğer olduğu görülür.

Metin üzerinden okuma çalışmaları yapılarak diksiyona, konuşmaya katkı sağlanır. Dinleyiciler önünde yapılan bir okuma, okumadan çıkıp konuşmaya dönüşür. Sesli okuma bir anlamda yarı hitap, yarı demeç, yarı hazırlıklı konuşmadır. Sesli okuma yalnız başına yapılmıyorsa çoğunlukla bu durumda iletişimsel bir etkinlik olup konuşma gibi iletişimsel dil becerileri kategorisine giren bir okuma tekniğine dönüşür.

Okuma ve konuşma birbirini taklit etseler de birey, ne okuduğu gibi konuşmalı ne de konuştuğu gibi okumalıdır. Çünkü konuşur gibi okuyan biri, metnin bilimsel ve sanatsal ağırlığını ortadan kaldırabilir. Okuduğu gibi konuşan biri ise samimiyetten uzak, tekdüze, mekanik ve robotik olarak değerlendirilebilir.

Günlük dilde kullanılan "plağa okumak”, "mikrofona okumak", "vokal kaydı", "ses kaydı" vb. kullanımlar da yine okuma ve sesletimin kesiştiği noktalardır. 
TDK deyim ve atasözleri sözlüğünde okuma ve konuşmanın ortak noktada buluştuğu deyimler bulunur. "Ezber okumak" "bir metni veya sözü herhangi bir yere bakmadan bellekte kalan biçimiyle söylemek', "ezberden okumak" 'daha önceden belleğine aldı̆̆ için herhangi bir yere bakmadan söylemek', "gazel okumak" birinci anlamıyla 'gazel söylemek', "Lahavle çekmek (okumak)" 'lahavle sözünü söylemek', "name okumak” 'herkesin bildiği deyimleri veya sözleri söylemek', "sala vermek (okumak)" '1) minarelerde salat okuyarak cuma namazını haber vermek, 2) bir kimsenin ölümünü, minareden salat okuyarak duyurmak', "yave okumak” 'gereksiz söz söylemek, boşa konuşmak' anlamıla belirtilmiştir. Okyanus Ansiklopedik Sözlük'te ise bu anlamda "gizliyi düğün evinde okumak”, 'saklanması gereken şeyi herkese açıklamak' (Tuğlacı, 2. Cilt, 1985: 654) şeklinde bir deyim bulunur.

Her ne kadar okuma, anlama ve konuşma, anlatma becerisi olsa da sesli okumalar, ezberden veya metne bağlı sesletimler; okuma ve konuşmanın iç içe geçtiği, aynı düzlemde buluştuğu ortak bir beceri alanıdır. Bu alanda okumaya konuşma, konuşmaya okuma denilebilir. Birey, metni sesleterek veya zihnindeki bilgileri açığa çıkararak her iki beceriyi birlikte kullanır. Okumanın bu anlamı hem literatürde hem de günlük dilde sıkça karşımıza çıkar.

\subsection{Okumak-deşifre etmek}

Çokanlamlı bir sözcük olan okumanın bir diğer anlamı 'Bir şeyin anlamını çözmek'tir (Güncel Türkçe Sözlük, 5. anlam). Sözlükte bu anlamı açıklamak için 'şifre okumak' örneği verilmiştir. Bu anlam, şifrelenmiş kodların bir amaç doğrultusunda çözümlenmesine vurgu yapar. Ancak şifrelenmiş bilgi, söz konusu şifreyi oluşturan kodların bilgisine sahip herkesin kolaylıkla deşifre edeceği bir yapıda değildir. Bu bakımdan bu tür bir okuma, yazı karakterlerini okumadan ayrılır. İlk okuma eğitimini alan hatta herhangi bir eğitim almadan dilin yazıdaki karakterlerini, bunların kullanımını ve mantığını çözen herkes, okumayı gerçekleştirir ve kendini geliştirecek okumalara yönelebilir. Ancak şifre okumak, şifre çözmek özel bir bilgi, yetenek, uzmanlık veya tecrübe gerektirebilir. Günümüzde ise deşifre etme yeteneğini insan makineye, sanal zekâya kaptırmıştır. Mısır piramitlerinin gizemini, oradaki güç yazıları çözmeye çalışan, deşifre edebilmek için yıllarını veren insanoğlu, teknolojik bir alette kullandığı uygulamanın unuttuğu şifresini yine sanal zekâdan destek alarak bulabilmektedir.

Okumanın yazılmış, çizilmiş ve anlaşılmayı bekleyen parçaları çözmeye dair bu anlamı eğitimde; bilmece, bulmaca, şifrelenmiş oyunlar, mantık soruları, zekâ oyunları vb. materyallerle ilişkili sözel ve sayısal akıl yürütmeler biçiminde kullanılmaktadır.

Doğrudan bağlantılı olmasa da "dudak okuma” da bu kategoride ele alınabilir. Dudak okuma, bir anlamda, sessiz konuşmaların okunması, gözle yapılan dinlemedir. İşitme engelli bireyler, dudak okumayla anlama ulaşırlar.

\subsection{Okumanın inançlarla ilişkisi}

Okumanın inanç yönüyle (dinî inanç, batıl inanç) kazandı̆̆ı anlamlar da vardır. Güncel Türkçe Sözlük'te okumanın 6. anlamı 'hastalı̆̆ı iyi edeceğini ileri sürerek okuyup üflemek, üfürükçülük etmek' açıllamasıyla verilir. Bu anlam, "okuyup üflemek" deyimiyle de kaynaklarda yer alır. Nazardan korunmak, hastalıklardan korunmak, ölmüşlerin ruhuna ulaştırmak vb. amaçlarla okuyup üfleme biçiminde gerçekleşen bu eylem, sözcüğün gerçek anlamıyla, okuyup üflemedir. Dua okunur ve nefes verilerek, üflenerek ayin tamamlanır.

\footnotetext{
Adres $\mid$ Address

İstanbul Medeniyet Üniversitesi, Eğitim Bilimleri Fakültesi, Türkçe İstanbul Medeniyet University, Faculty of Education Sciences, ve Sosyal Bilimler Eğitimi Bölümü, Türkce Eğitimi ABD Cevizli Turkish and Social Scinces Education, Turkish Language Teaching Kampüsü, Kartal-İstanbul/TÜRKIYE $\quad$ Education, Cevizli Campus, Kartal-İstanbul /TURKEY e-posta: editor@rumelide.com 1 e-mail: editor@rumelide.com
} 
Okumanın dua okuma (duayı bir metne bakarak sesli olarak okuma veya duayı ezberindeki şekliyle sesletme) anlamında deyim ve atasözleriyle kullanıldığı görülür. "Kuru sofraya molla dua okumaz." (Saraçbaşı ve Minnetoğlu, 1978: 271, 275) ve "Okunan yir eyü olur." sözleri atasözü olarak belirtilmiştir (İzbudak, 1936: 35).

Okumanın inanç bağlamında kullanıldığı bir anlam da "kıraat ile okumak"tır. 'Kur'an'ı usul ve kurallarına uygun ve düzgün olarak okumak' (Çağbayır, 3. Cilt, 2007: 2615) anlamında verilir. “Avcundan okumak" ise 'fala bakmak' (Çağbayır, 1. Cilt, 2007: 360) olarak belirtilmiştir.

TDK deyim ve atasözleri sözlüğünde "bela okumak" 'birine ilenmek', "lanet okumak" 'bir kimsenin Tanrı'nın merhametinden yoksun kalmasını dilemek', "mukabele okumak" 'topluluk karşısında dinleyicilerin takip edebileceği biçimde Kur'an'ı okumak', "rahmet okumak” 'Tanrı'nın merhamet ve bağışlaması için dua etmek' açıklamasıyla verilir. Ayrıca Bölge ağızlarında (Salman, Akkuş-Ordu) 'dinine düşkün, sürekli dua eden, dualı anlamında' "ağzı okumuş olmak” deyimi kayıtlıdır (Aksoy, 2004: 221).

Okumanın inançlarla bağlantısı, daha çok, dine ait okunacak çeşitli eserler ve günlük hayatta veya ayinlerde okunup sesletilecek dualar, ezberlerle ilişkilidir. Kur'an-ı Kerim’in, Türkçede tarihî süreçte birçok dönemde olduğu gibi günümüzde de okumayla ilişkilendirildiği, Kur’an-ı Kerim’i okuyup öğrenmenin ve sıkça okumanın temel okuma eğitimleri içinde yer aldığı görülür.

Kültürün en önemli dinamiklerinden olan dinin etkisi, kültürümüzde okumanın, kutsal kitabı okumak; kitabın ise Kur'an-ı Kerim olarak bilinmesiyle de anlaşılabilir. Kur'an-ı Kerim'den parçalar, dualar okunması; ezanın ibadete çağrı yönü, okumayı yüceltmiştir. Hadisler ve dört halifenin okumaya dair nasihatleri de okumanın hem inanç hem de zihinsel gelişim bakımından önem kazanmasına etki etmiştir.

Dua okumanın karşısında yer alan beddua okuma ise yine inanç ekseninde ele alınabilecek bir kullanımdır. Kişinin haksızlık gördüğü, zor durumda kaldığı, etki ve gücünün yetmediği noktalarda Yaratıcıdan veya tabiat güçlerinden buna sebep olanların benzer şekilde veya daha fazla acı çekmesini istemesi biçimindeki bu tür yakarışlar da kalıplaşmış ifadelerin veya çeşitli ezberlerin okunup sesletilmesi biçiminde gerçekleşir.

Dinin gelenekselleşmiş ve kurallara bağlı inanç bütünü dışında, insanların çeşitli fantezileri ve geleceği anlamaya dair hayal ve kaygıları sonucu yöneldikleri batıl inançlar da okumayla ifade edilebilir. Yukarıda belirtildiği gibi, "avcundan okumak" ifadesi, fala bakma anlamında olup avuç çizgilerinden yola çıkarak geleceğe dair çeşitli çıkarımlar yapılması, öngörülerde bulunulmasıdır.

\subsection{Okumak-gizli olanı açıklığa kavuşturmak}

Okumanın bir diğer anlamı (sözlükteki 7. anlam) 'bazı belirtilerle bir anlamı, gizli bir duyguyu anlamak, kavramak' olarak belirtilmiştir. Okumanın gizlenmiş, kapalı, ilk bakışta anlaşılmayan şeyleri; üzerinde düşünerek, incelemelerde bulunarak veya tecrübelerle anlaşılır kılmak biçiminde açıllanacak bu anlamı, daha çok, insan ilişkilerinde açığa çıkar. Bu bakış açısıyla neler okunabilir? Duygular, düşünceler, zihin, davranış, beden dili vb.

Türkçede, okumanın gizli şeyleri açıklığa kavuşturmak biçimindeki anlamını yansıtan çeşitli deyimler görülür. TDK deyim ve atasözleri sözlüğünde (birinin) "içini okumak” 'birinin gizli saklı düşüncelerini 
anlamak, "düşüncesini okumak" 'bir kimsenin ne düşündüğünü anlamak', "gözlerinden okumak" 'düşüncelerini bakışlarından sezmek', "kalbini okumak" 'birinin duygu ve düşüncelerini, niyetini anlamak', "gözleri velfecri okumak" 'kurnazlığı gözlerinden belli olmak', "mektubu dışından okumak" 'bir kimsenin içinden geçeni yüz çizgilerinden anlamak', "yüzünden okumak" ikinci anlamıyla 'herhangi bir durumu yüzünden anlamak' anlamında verilmiştir. Okyanus Ansiklopedik Sözlük’te ise bu anlamda "ruhunu okumak" (birinin) 'benliğini tamamen anlamak, düşüncelerini kavramak' (Tuğlacı, 8. Cilt, 1985: 2437) sözü açıllamasıyla yer almıştır.

Bu tür bir okumanın yine kodlarla, ancak bu kez davranış kodlarıyla ilişkili olduğu söylenebilir. İnsan davranışının tekrar eden, birbirine benzeyen ve aynı anlamları karşladığı bilinen özellikleri, çeşitli çıkarım ve tecrübelerle anlaşllabilmektedir. Örneğin, çocukların beden dili tepkilerini "okumak" kolaydır. Benzer şekilde yetişkinlerin duygusal anlarda, coşku ve heyecana bağlı durumlarda duygu ve düşüncelerini anlamak (okumak) zor olmaz.

\subsection{Okumak-yorum ve değerlendirmede bulunmak}

Güncel Türkçe Sözlük’te okumanın 8. anlamı mecaz olarak “değerlendirmek” anlamıyla verilmiştir. Sözlükte bu anlama dair bir örnek sunulmamıştır. Şöyle bir örnek verilebilir: 'Bu sonucu tahmin edildiği şekilde okumalısın!' Bu anlam, daha çok, yaşanıp bitmiş şeylerin bir muhasebesi, yorumu, doğru anlaşılması, sonuçların fark edilmesiyle vb. ilgilidir.

TDK deyim ve atasözleri sözlüğ̈̈nde geçen “tersinden okumak” deyimi, ikinci anlamıyla 'olayı veya bir sanat eserini farklı biçimde değerlendirmek, yorumlamak’ biçiminde açıklanmıştır.

Okuma, alıcı bir beceriyken bu anlamıyla ifade edici, tepkiye dayalı bir beceriye dönüşmektedir. Okumanın, sembollerden anlam çlkarma özelliği bu kez yaşanan durumlardan, olay ve olgulardan bir sonuca ulaşmak, var olan şeyleri yerli yerine koymak, neden-sonuç ilişkisini kurmak ve olan bitene ad koymak biçiminde bir anlam kazanır. Bu anlam, günlük hayatta "Doğru okumalısın!", "Bu firsatları görmek, okumak gerekir.”, “Aldığın bu puanın oluşturacağı sonuçları iyi okumalısın!” vb. cümlelerde netlik kazanır.

\subsection{Okumanın argoda kullanımı}

Okumanın aşağılayıcı bir anlamda, kaba bir söz, bir küfür olarak kullanılabileceği pek düşünülmez. Oysa birçok dilde olduğu gibi, Türkçe argoda da, okumanın ve okuma sözcüğünün çekimlerinin çeşitli kaba, aldatıcı, komik, alaycı ifadeleri ve küfürleri karşıladığı; sövme ve hakaret anlamında kullanıldığı görülür. Argoda okumanın kazandığı anlamların, karakterleri anlamlandırmak, şifre çözmek ve sesletmek anlamındaki temel anlamlarından tamamen uzaklaşmadığı fakat okumayı küçümseyici, okumayla alay eden bir yaklaşımın olduğu sezilmektedir.

Güncel Türkçe Sözlük'te okumanın 9. anlamı argo olup ‘sövmek, küfretmek’tir. Söz konusu anlama ilişkin örnek verilmemiştir. Bu anlam, diğer kaynaklarda "ceddine okumak" (soyuna sopuna sövmek), "geçmişine okumak" (sövmek) (Tuğlacı, 10. Cilt, 1985: 78, 144), “defteri kebir(in)den okumak” (ağır küfürler etmek) şeklinde sözcük gruplarıyla verilir (Devellioğlu, 1980: 75; Aktunç, 1998: 86). Okumanın bir başka argo kullanımı "yuf okumak" biçimindedir. Bu kullanımda 'lanet etmek' (Kadri, 4. Cilt, 1945: 852), 'üzüntü ve yazıklanmalarını bildirmek' (Çağbayır, 5. Cilt, 2007: 5375) anlamı bulunur.

\footnotetext{
Adres $\mid$ Address

İstanbul Medeniyet Üniversitesi, Eğitim Bilimleri Fakültesi, Türkçe ve Sosyal Bilimler Eğitimi Bölümü, Türkce Eğitimi ABD Cevizli Turkish and Social Scinces Education, Turkish Language Teaching Kampüsü, Kartal-İstanbul/TÜRKIYE $\quad$ Education, Cevizli Campus, Kartal-İstanbul /TURKEY e-posta: editor@rumelide.com 1 e-mail: editor@rumelide.com
} 
Kaynaklarda okumanın 'ihbar etmek, ispiyonlamak' (Devellioğlu, 1980: 126), 'itiraf etmek' (Aktunç, 1998: 225), 'gördüğü zor karşısında bildiği her şeyi söylemek; yasa dışı işler hakkında ilgili makama bilgi vermek; ötmek' (Çağbayır, 4. Cilt: 3602) anlamlarıyla da kullanıldı̆̆ı belirtilir.

Argonun kendine ait bir dil geliştirdiği bilinir. Günlük dildeki “ezan okumak” argoda olumsuz bir anlam kazanarak 'bağıra çağıra, uzun uzun azarlamak' (Aktunç, 1998: 107) anlamıyla kullanılır.

Aktunç’un (1998: 314, 132, 152, 191, 83) argo sözlüğünde, içinde “okuma”nın geçtiği şu sözler yer alır: "Hariçten gazel okumak” 'ilgili ve bilgili olmadığı bir işe karışmak'; “içine okumak” 'içine s..mak’; "katakulli okumak" 'aldatıcı konuşmak, yalan söylemek'; "maval okumak" 'yalan söylemek, yalan haber vermek, laf kalabalığı yapmak, uzun uzadıya konuşmak, dırdır etmek'; "dikiş okuması” (özellikle İstanbullu çingeneler arasında) 'belirli bir yolu yöntemi olan ağız dalaşlarında karşılıklı söylenen açık saçık tekerleme, bu tekerlemeleri söyleme.' Okumanın, okunmak biçimindeki çekimi de argoda "duası okunmak” deyiminde farklı bir anlam kazanmıştır. Bu deyim, 'ölmek, öldürülmek' anlamlarıyla kullanılır (Aktunç, 1998: 94).

Okutmak ise argoda 'bir şeyi satarak elinden çıkarmak, satmak' (Güncel Türkçe Sözlük; Devellioğlu, 1980: 126; Aktunç, 1998: 225) anlamıyla verilir. Kadın argosunda "yumurtayı sarısız okutmak" deyimi, 'Göz boyayıcı satıcılar için alay yollu olarak kullanılır' (Bingölçe, 2005: 183). Okutmanın argodaki bir kullanımı da "pabucu büyüğe okutmak" deyimidir. Bu deyim, 'Akılsızca davrananlar için alaylı bir öğüt olarak kullanılır' (Tuğlacı, 7. Cilt, 1985: 2267). "Bu ne hal, sen kendini pabucu büyüğe okut." biçiminde kişiye tutarsız davranışlarından dolayı kendini bir üfürükçüye okutup da akıllanması için söylenir (Aksoy, 1984: 455). Bu kullanım; üfürükçüye giderek kendisine dua okunmasını istemek, efsun yaptırmak vb. anlamlarıyla okumanın inançla kesiştiği argo bir anlamdır.

TDK deyim ve atasözleri sözlüğünde okumanın argo anlamda kullanıldığı deyimler ise şunlardır: (bir şeye) "Fatiha okumak" 'o şeyden umudunu kesmek', (biri ötekinin) "babasına rahmet okumak" 'hakkında iyilik düşünmemek', (birinin) "ciğerini okumak” 'onun aklından geçenleri, gizli düşüncelerini bilmek', (birinin) "künyesini okumak" 'ayıplarını yüzüne vurarak bir kimseye sövmek' "bülbül gibi konuşmak (okumak)" ikinci anlamıyla 'itiraf etmek', "canına ezan okumak" 'bir kimsenin hakkından gelmek, öldürmek', "canına okumak” 'berbat ve perişan etmek', "çarkına etmek (okumak)” 'birine büyük kötülük yapmak veya işini bozarak zarar vermek', "gazel okumak" ikinci anlamıyla 'oyalamak veya kandırmak üzere boş sözler söylemek', "hariçten gazel okumak” ikinci anlamıyla (İlk anlamı yukarıda Aktunç'un eserinde belirtilmiştir.) 'bir konuşmaya yersiz ve zamansız katılmak', "içinden okumak" ikinci anlamıyla 'sessiz bir biçimde sövmek', "martaval atmak (okumak)" 'inanılmayacak sözler söylemek, yalan söylemek', "masal okumak" (anlatmak) 'inandırıcı olmayan, oyalayıcı sözlerle kandırmaya çalışmak' açılamasıyla verilmiş̧tir.

Okumanın argodaki kullanımlarında; kod çözme, karakter okuma, sesli okuma, sesletme gibi anlamların tersinden ele alındığı, alaya alındığı, hakarete ve küfre dönüştüğü görülür. Örneğin, "rahmet okuma"nın gerçek anlamıyla, okuma ve inanç ekseninde kesişen olumlu yönü argoda ters yüz edilerek olumsuz bir anlamı karşılamak için kullanılmıştır.

\subsection{Okuma-davet etme}

Güncel Türkçe Sözlük'te okumanın 10. anlamı şu şekilde verilmiştir: Halk ağzında 'bir yere çağırmak, davet etmek, okuntu göndermek.' Bu anlam, Türkçenin tarihî sürecinde, okumanın ilk ve temel 
anlamıdır. Ancak günümüzde sözlükte, sözcügün çokanlamlılık sıralamasında 10. sıraya, yani son sıraya yerleşmiştir. Türk dili tarihinde okumanın geçmişten günümüze eserlerdeki yansımalarına bakıldığında okuma(k); Orhun Abideleri’nde 'çağırmak, davet etmek' anlamıyla karşımıza çıkar. Bilge Kağan Abidesi Doğu Cephesi 28. satırda “...okıgalı kelti.” (...çağırmak için geldi.) biçiminde görülür (Ergin, 2011: 76).

Eski Oğuzcada 'çağırmak, davet etmek' anlamıyla kullanılmış olan (Turan, 2001: 78) okumanın, Türkçede günümüzdeki temel anlamıyla kullanımını Uygur döneminden bu yana görmek mümkündür: "Okı-(okımak): çağırmak, okumak" (Gabain, 1998: 288). Maytrisimit’te ukıt-(ukıtmak): 'anlattırmak, öğretmek' anlamlarında kullanılmıştır (Tekin, 1976: 301). Sözcük, Altun Yaruk'ta "okımak" biçiminde geçmekte ve 'okumak, öğrenmek, çağırmak, söylemek' anlamlarında kullanılmaktadır. Hatta söz konusu eserde okumak ve söylemek birlikte kullanılmaktadır. Bu da okumanın 'sesletmek, söylemek' gibi anlamlar taşıdığını da gösterir. Okıdum sözledim-okudum söyledim (186.21), okınglar sözlerler-okuyunuz söyleyiniz (198.15-16), okısar sözleser-okusa söylese (175.15), okıgalı sözlegeli-okuyacağımızı söyleyeceğimizi (182.21), okıdaçı sözledeçi-okuyacak söyleyecek (193.10) (Ölmez, 1991: 74, 111).

“Etimolojik sözlüklere bakıldığında 'yazılı bir metni yüksek sesle okumak, seslendirmek' anlamındaki sözcükle ilk olarak Uygur Türkçesi dönemindeki metinlerde karşllaşıyoruz. (Clausan, 1972), Uygur dönemi eserlerinden olan Prens Kalyanam Kara ve Papam Kara (Orkun, 1940), Altun Yaruk (Kaya, 1994), Türkçe Mani El Yazıları (Manichaica) (Coq, 1912-1922), Eski Türk Şiiri (Arat, 1991) ve Uygurca Üç Hikaye'de (Himran, 1946) bu kelimenin 'davet etmek, çağırmak vb.' anlamlarının yanında bugünkü ‘okumak' anlamını da görebiliriz” (Zal, 2007: 77).

Kutadgu Bilig’de okumanın günümüzdeki anlamıyla da kullanıldı̆̆ı görülür (Arat, 1959: 195):

"bitise okısa eşitse sözüg

anın ötrü bilge kılur er özün” (b. 2629)

(Yazmalı, okumalı ve başkalarının sözünden de istifade etmelidir, insan bu suretle âlim olur.)

Divanü Lugati't-Türk’te “okumak”; 'okumak, çağırmak' (Atalay, 1986: 333, 254) anlamındadır. Atebetü'l-Hakayık (Arat, 1992: 145) ve Divan-ı Hikmet’te (Bice, 1993: 180) de okumanın bugünkü temel anlamıyla (metni, duayı vb. okumak) kullanıldığı görülür.

Okumanın geçmişte, daha çok, 'davet etmek, haber göndermek' anlamında kullanıldığı ve okunmak (davet edilmek), okuşmak (karşılıklı davette bulunmak) vb. çekimleriyle dilde yaşadığı görülür. Harezm, Kıpçak ve Çağatay dönemlerinde de okumanın 'okumak, çağırmak, sesli okumak, yazılan bir nesneyi gözden geçirmek, yüksek sesle okumak, aramak, dua okumak vb.' anlamlarıyla kullanıldığı belirtilir (Grönbech, 1992: 77; Toparlı vd., 2007: 211; Battal, 1934: 114-124; Courteille, 1870: 69, Çağatay, 1977: 158; Atalay, 1970: 104).

Selçuklu ve Osmanlı Devleti dönemlerinde, okumanın 'davet etme, çağırma, söyleme, hatırlama, ad verme, kitap okuma, yüksek sesle okuma, dua okuma vb.' anlamlarıyla kullanıldığı görülür (Mansuroğlu, 1947: 35; Timurtaş, 1972: 33; Sami, 1900: 212; Dilçin, 1983: 161, Dilçin, 1996: 2947).

Ömer Asım Aksoy'un bölge ağızları derlemesinde "Okunmadık düğüne kel oğlan gider.” (Çayköy, Niksar-Tokat) (Aksoy, 2004: 175) sözü yer alır. Anadolu ağızlarında "imeci okumak" "iş için halkı imeceye çağırmak’ (Sinop, Samsun/Derleme Sözlüŭü, 7. Cilt, 1974: 2435) anlamında kullanılır.

\footnotetext{
\begin{tabular}{r|l} 
Adres & Address \\
İstanbul Medeniyet Üniversitesi, Eğitim Bilimleri Fakültesi, Türkçe & İstanbul Medeniyet University, Faculty of Education Sciences,
\end{tabular} ve Sosyal Bilimler Eğitimi Bölümü, Türkce Eğitimi ABD Cevizli $\quad$ Turkish and Social Scinces Education, Turkish Language Teaching Kampüsü, Kartal-İstanbul/TÜRKIYE $\quad$ Education, Cevizli Campus, Kartal-İstanbul /TURKEY e-posta: editor@rumelide.com 1 e-mail: editor@rumelide.com
} 
İzbudak’ın sözlüğünde “Eşeği düğüne okumuşlar ya su eksükdür ya odun eksükdür.” (İzbudak, 1936: 22) deyimi bulunur.

TDK deyim ve atasözleri sözlüğünde "meydan okumak" deyimi 'korkmadığını, çekinmediğini açıkça bildirmek, kavga veya yarışmaya çağırmak' (meydane okumak-meydana çağırmak/Nişanyan, 2009: 91) anlamındadır. Tarama sözlüğünde bu anlamla ilişkili "mumla okumak" deyimi, "çok isteyerek çağırmak' (Dilçin, 1983: 161) açılamasıyla verilmiştir.

Okumanın çağırmak ve davet etmek anlamını günümüzde standart Türkçede bulmak güçtür. Bu anlam, daha çok, ağızlarda yaşamakta ve kullanılmaktadır. Örneğin, "meydan okumak” ifadesi kalıplaşmış biçimiyle anlaşılır ve bir müsabakada rakibi meydana çağırmak, düelloya davet etmek gibi bir anlamının olduğu “okumak” sözcüğünden değil, kalıplaşmış yapının bütününden çıkarılır.

\subsection{Görsel okuma}

Okumanın farklı anlamlarından biri de görsel okumadır. Okumanın görsel okuma anlamına dair Güncel Türkçe Sözlük’te herhangi bir açıklama bulunmamaktadır.

MEB, 2005 Türkçe 1-5. Sınıflar Öğretim Programı'nda görsel okumanın da bir beceri olduğunu belirtir ve hatta görsel okuma, bu programda okuma becerisinden farklı bir başlık olarak ele alınır. Eski dönemlerde sadece ders kitapları, kaynak kitaplar, ortama getirilen afiş, resim ve broşürlerin vb. okunması biçiminde gerçekleşen görsel okuma, günümüzde teknolojik aletlerin (projeksiyon, televizyon, tablet, cep telefonu vb.) yaygınlaşmasıyla her an maruz kalınan daha kapsamlı ve detaylı bir okumaya dönüşmüştür.

Günümüzün ulusal ve uluslararası test ve sinavlarında (LGS, PISA vb.) okuma becerisinin ölçülmesinde görsel okuma yeterliğinin ön plana çıktı̆̆ görülmektedir. Metin okumanın yanında tablo, şekil, grafik okumaya dair sorular bulunmaktadır. Söz konusu okuma, yeni bir okuma ve anlama becerisidir.

Okumanın özünde tanıma ve algılama vardır. Bu, ister yazı karakterleri olsun ister görseller, bireyin aynı çabayı göstermesini gerektirir. Yazıdaki anlamı karakterlerin uygun birleşiminden seçip çıkaran zihin; karakter, kod ve harfler yerine, aynı işlemi, tanıyıp fark edebildiği görselleri bir bütünlüğe ulaştırarak yapar. Görsel okumada, görsellerdeki her bir çizgi, desen, renk, şekil ve detayın vb. birer sözcük gibi okunup bir anlama dönüştürülmesi; görsel bir dünyanın kitapları, sayfaları diyebileceğimiz afiş, resim, tablo, şekil, sembol, fotoğraf, şema, harita, grafik, diyagram vb. materyali anlamlandırma söz konusudur. Nesnesi değişse de okumanın çözümleme anlamı aynıdır.

Çocuklar önce görsel okumayla anlamayı gerçekleştirir. Hayati Akyol'un belirttiği gibi, görsel temelli öğrenme, dilsel temelli öğrenmeden önce gelir (Akyol, 2013:128).

Geçmişte olduğu gibi günümüzde de kullanılan bir yöntemle kitaplarda, metinlerle birlikte, metinlerin hemen yanında görseller bulunmakta ve bu görseller metinde söz edilenlerin anlaşılmasını kolaylaştırıp metni takip etmeyi olumlu etkilemektedir. Hatta bu görsellerin unutulmaz ve kalıcı olduğu söylenebilir. Ancak yazıya destek veren, yeri geldiğinde zevk uyandıran bu görsellerin, okuma anlamada (Yazı birincil özelliktedir.) ikincil bir role sahip olduğu düşünülür. Oysa günümüzde bu düşüncenin giderek değiştiği, görselin metni ve dolayısıyla okumayı anlaşılır kılmasından çok, görsel okuma biçiminde doğrudan görselin okunması ve metnin aradan çekilmesinin gerçekleştiği de 
söylenebilir. Örneğin, eğitici nitelikte düşündürücü bir karikatür, metin olarak derste kullanılabilmekte ve etkinlikler bu karikatür üzerinden planlanabilmektedir.

Okumanın günümüzde kâğıttan, ekrana yöneldiği görülür. Bilgi artık kâğıtta değil, ekranda okuyucunun karşısına çıkar. Ekran okuma, ekranik okuma, ekranik yazma, ekranik düşünme vb. denilen bu tür okumalar ve yeni beceriler, okumanın çağın gerektirdiği dönüşüme ayak uydurması sonucunda gelişmekte ve bu tür bir okuma incelendiğinde ekrandan okumanın olumlu ve olumsuz yönleri olduğu görülmektedir (Güneş, 2014: 378-379).

Matbu kaynaklardan okuma, dijital okuma karşısında direnmektedir. MEB, hem matbu kaynaklardan (ders kitapları ve bu kitaplardaki metinler) hem de elektronik ortamlardan (akıllı tahta, EBA, dijital ortamdaki ses ve video kayıtları vb.) öğrenciye ulaşmaktadır. Ekran okuma, e-okuma, elektronik okuma, bilgisayardan, tabletten, cepten vb. okumalar; internet ve bilgisayar destekli okumalar vb. şeklinde çeşitlilik kazanan bu yeni okumalar, yeni anlam ve anlamaları beraberinde getirmektedir.

\subsection{Manyetik okuma, robotik okuma}

Okumanın insanlar tarafından yapılan bir etkinlik olmasının ötesinde günümüzde sanal zekânın yaptığı metin okumaları, robotların okumaları ve makinelerin manyetik okumaları da farklı bir okuma türü ve anlamı olarak karşımıza çıkar. Elektronik aletlerde (bilgisayar, tablet, cep telefonu vb.) metinleri, mesajları, yazıları okuyan programlar veya uygulamalar bulunmaktadır. Ancak bu okumalar, daha çok, tekdüze ve robotik okumalardır.

Makinelerin manyetik okumaları ise okumanın kazandığı farklı bir anlamı ifade etmektedir. Bellekten okuma, optik okuma, DVD okuma, kart okuma, plak okuma vb. türlerde okumalar bulunmaktadır. Genellikle manyetik okumayı yapan alete "okuyucu" denilir. Bu bakımdan okuyucu ile okur arasında bir nüans oluşmaktadır. Okuma eylemini gerçekleştiren kimseye "okur" denilmesi daha doğru olacaktır.

\subsection{3. İlk okuma}

Okumanın, bir başka farklı anlam ve kullanımı "ilk okuma"dır. "Okuryazarlık" sözcüğü de Türkçede okumanın bu anlamıyla ilişkilidir. "Okumanın, çoğu zaman ilk okuma ve yazmayı öğrenmiş olma, yani okuryazarlık (literacy) anlamında kullanıldığı da görülmektedir" (Karatay, 2014: 2). Okuryazarlıkta ilk okuma ve yazma faaliyetleri bir aradadır. "Bireyin, kâ̆ğı üzerindeki birtakım imleri birbirine çatarak sesbirimler, sözcükler, sözcük dizileri, anlamlar çlkarabilme, kendi demek istediklerini de o imler aracılı̆̆ıyla kâğıt üstüne dökebilme becerisi” (Göktürk, 1983: 78) olan okuryazarlığın okuma boyutu ele alındığında, ilk okuma denilen evrenin başlarında, metinlerin birey tarafından ne kadar anlaşıldığından çok, bireyin kağıt üstündeki veya başka zeminlerdeki (ekran, tabela, billboard vb.) karaltıları uygun şekilde tanıması ve birleştirmesi hedeflenir. "Çocuk bu aşamada edindiği ipuçlarından hareketle kelimeyi resim gibi yani bütün olarak tanımaktadır. Bu okuma öncesi bir durumdur" (Güneş, 2014: 140).

Okumayı öğrenmek mekanik bir süreç iken öğrenmek için okumak zihinsel ve psikolojik bir süreçtir. Okumanın mekanik yönüne ilişkin anlamı, Güncel Türkçe Sözlük’te "okumayı sökmek” (okula yeni başlayan öğrencinin, verilen eğitim sonrası okumaya başlaması, okuma becerisini kazanması) deyiminde görülür. Burada okumanın anlama ulaşma boyutu yok denecek kadar azdır. Gösterilen

Adres

İstanbul Medeniyet Üniversitesi, Eğitim Bilimleri Fakültesi, Türkçe ve Sosyal Bilimler Eğitimi Bölümü, Türkçe Eğitimi ABD Cevizli Kampüsü, Kartal-İstanbul/TÜRKIYE e-posta: editor@rumelide.com 
gayret, daha çok, psikomotor süreçlerin öne çıtığı bir çabadır. "Alfabeyi okumak”, "okumaya geçmek" biçimindeki birleşik sözcüklerle de bu süreç ifade edilir.

Karakter ve işaretlerin ses değerlerini tanımakla başlayan süreç, karakter ve işaretlerin farklı kombinasyonlarıyla kurulmuş sözcük ve cümlelerden metne ve anlama ulaşmaya uzanır. İşaretin sesini tanıyı çıkarmak da okumadır. Fakat bu okuma büyük oranda mekaniktir. Sadece çözmek (dilin abecesini), tıpkı sökmek gibi mekanik iken çözüp anlamak zihinsel ve gerçek okumadır.

Okuryazarlığın günümüzde tanımı ve anlamı genişledi; bilgisayar okuryazarlı̆̆ı, medya okuryazarlığı, görsel okuryazarlık, dijital okuryazarlık, kültür okuryazarlığı gibi yeni okuryazarlıkları tanımlayıp açıklamak için kullanılmaya başlandı. "Dijital dünya, yeni teknolojilerin de katkısıyla okuryazarlığın anlamına bu temel becerilerin yanında iletişim, araştırma, bilgiye ulaşma ve kullanma, mesajlar hakkında kritik düşünme, verileri anlama ve değerlendirme becerilerini de ekleyerek genişletti” (Ertem, 2014: 4).

\subsection{Okumanın, çeşitli durum ve davranışları ifade etmesi}

Okumanın, bilinen ve sözlükte sıralanan anlamlarının dışında, mecaz anlamıyla, çeşitli durumları ve insan davranışlarını ifade edecek şekilde kullanıldığı da görülür. Türkçede, kaynakların ortaya koyduğu bazı sözcük, sözcük grubu, deyim ve atasözlerinde; Anadolu ağızlarındaki kalıplaşmış söz ve ifadelerde okuma günlük hayatta insan ilişkilerine yansıyan bazı durum ve davranışların yerini tutar.

TDK deyim ve atasözleri sözlüğünde geçen "bildiğini okumak" deyimi "herkes ne derse desin bildiği, istediği gibi davranmak' anlamıyla verilir. Bir başka kaynakta "baştan çıkarmaya kurt masalı okumak" deyimi 'bir sürü bahaneler uydurarak karşısındakini kandırmak, ayartmak, istediği yola getirmeye çalışmak' (Tuğlacı, 10. Cilt, 1985: 59) açılamasıyla verilmiştir. "Kulağına okumak” ise 'ihtar etmek' (Kadri, 3. Cilt, 1945: 887) demektir. Akyalçın'ın kaydettiği "okumada âlim, gezmede seyyah" (Her şeyin en iyisini bilirmiş gibi görünmek. Çokbilmişlik edenler için söylenir. Akyalçın, 2012: 411) ve "okuma bilmez, gözü defterdarlıkta" (Yeteneği ve çapı üzerinde işlere kalkışanlar, kendini aşan işlere soyunanlar için söylenir. Akyalçın, 2012: 411) deyimleri de mecaz anlamlarıyla, okumanın çeşitli olumsuz davranışları karşıladığını gösterir.

Ötüken Türkçe Sözlük'te geçen "sübbeyi kubbe okutmak" deyimi ise 'zora koşmak, olmayacak işler yaptırmak' (Çağbayır, 4. Cilt, 2007: 4366) açılklamasıyla verilmiştir. Ömer Asım Aksoy’un (2004: 249) bölge ağızları derleme sözlüğündeki "başına kurt kuranı okumak" (Baltalı, Çıldır-Kars) sözü "bir işin neden yapılmadığını, kandırıcı olmayan sözlerle uzun uzun anlatmak, birtakım sudan sebepler ileri sürmek' (Gaziantep deyim ve atasözleri içinde yer alır.) anlamındadır.

Okumanın çeşitli davranışları karşılayan kullanımlarına Anadolu ağızlarında da rastlanır. "Horsa okumak", 'inkâr etmek' (Yenimüslüman-Zile-Tokat/Derleme Sözlüğ̈̈, 7. Cilt, 1974: 2413) demektir. "Okumak” güney illerimizde ikinci anlamıyla 'beğenmek, saygı göstermek' (Ylldırım, 2006), “okutmak” ise 'surat asmak' (Kurşunlu-Çankırı/Derleme Sözlüğü, 9. Cilt, 1977: 3276) anlamında kullanılır.

Tarama sözlüğünde okumak üçüncü anlamıyla 'anmak, yâd etmek', okunmak birinci anlamıyla 'ad verilmek', "ogul okumak" ise 'evlat edinmek' açıklamasıyla yer alır (Dilçin, 1983: 161). TDK’nin deyim ve atasözleri sözlüğünde "Düşman düşmana gazel (Yasin) okumaz.” (Düşmandan ancak kötülük 
beklenir.), "Gelen gidene rahmet okutur." (Beğenmediğimiz bir kişinin yerine öyle birisi gelir ki eskisini aratır.) şeklinde iki atasözü bulunur.

Necmi Akyalçın'ın (2012: 168) atasözleri derlemesinde "Bakkal, tebeşirini okuyamaz." (İşini savsaklayarak yapan kişiler, kendi yaptıklarını da takip etmeyi başaramazlar.) ve Acaroğlu'nun sözlüğünde "Sarhoşun mektubu meyhanede okunur.", "Meyhanede yazılan, cehennemde okunur." atasözleri kayıtlıdır (Acaroğlu, 1992: 15, 107).

TDK deyim ve atasözleri sözlüğünde “adı bile okunmamak” 'birine veya bir şeye hiç önem verilmemek', "esamesi okunmamak" 'kendisine değer verilmemek, adı anılmamak', "tozdan dumandan ferman okunmamak" 'ortalık çok karışık olmak' deyimleri yer alır. Korkmaz’ın (1992: 55) "eskilik” başlı̆̆ı altında verdiği "akıl kulağına okumak" 'aklına getirmek, hatırına düşürmek' anlamındaki söz de bir deyim niteliğindedir.

Okumanın bağlamsal açıdan kullanımları dışında terimsel kullanımları da olabilir. Okumanın terimsel kullanımına bir örnek olarak "okuma oyunu" verilebilir. "Okuma oyunu yazarınca oynanmak için değil, okunmak için yazılmış oyun. Sahne gereklerine önem vermeyen oyun. Konusu teknik güçlüklerle kurulu, çok kişili, çok dekor isteyen, oynanmaya elverişli olmayan oyun”dur (Taner, 1966: 73).

\subsection{Okumayla ilgili birleşik sözcük ve ikilemeler}

Çalışmada okumanın farklı anlam ve kullanımları sınıflandırılırken tarama sonucu elde edilen veriler (okuma sözcüğünün çekimleri, deyim, atasözü vb. yapılar) ilgili başlığın altında verilmiştir. Özellikle deyimlerin dışında sıklıkla karşımıza çıkan birleşik sözcük ve ikilemeler ise şu şekildedir: ağıt okuma, alkış okuma, beddua okuma, destan okuma, dua okuma, ezan okuma, fal okuma, Fatiha okuma, ferman okuma, geçmişi okuma, geleceği okuma, harita okuma, hatim okuma, hikâye okuma, hutbe okuma, ilahi okuma, kaside okuma, kendini okuma, Kur'an okuma, mani okuma, mersiye okuma, mesnevi okuma, nota okuma, oku oku (bitmez), okuma yazma, okur okumaz, okuryazar, okuya okuya, okuyuvermek, ordan ordan okumak (Vecihe Hatiboğlu'nun çıkmalı ikileme dediği), remil okuma, sala okuma, şarkı okuma, şiir okuma, tekerleme okuma, uzun hava okuma, üstünkörü okuma, Yasin okuma, optik okuma.

\subsection{Okuma türleri}

Öğretim programlarında en fazla kazanıma sahip olan okuma becerisi, dil becerileri içinde tür ve çeşitliliği ile de dikkati çeker. Literatürde görülen okuma çeşitleri, temelde sesli ve sessiz okumaya dayanır. Bu araştırmada, birçok kaynağın incelenmesi sonucunda, alanda genel olarak bilinen okuma tür veya yöntemlerinin (sesli okuma, sessiz okuma, hızlı okuma, göz atarak okuma, not alarak okuma, özetleyerek okuma, işaretleyerek okuma, tahmin ederek okuma, soru sorarak okuma, söz korosu, okuma tiyatrosu, tartışarak okuma, metinler arası okuma, eleştirel okuma vd.) dışında okuma türlerinin olduğu görülmüştür. Araştırmacıları yeni çalışmalara yönlendirmek bakımından bunları toplu bir şekilde belirtmek mümkündür: açık okuma, ağır okuma, aşırı okuma, ayrıntılı okuma, baştan sona okuma, bina okuma, doğaçlama okuma, doğru okuma, doğrusal okuma, doğrusal olmayan okuma, düzgün okuma, eğri okuma, eski kitaplar okuma, eski yazı okuma, ezberden okuma, gelişigüzel okuma, gürül gürül okuma, heceleyerek okuma, ikinci dilde okuma, kâğıttan okuma, kararlı okuma, karşılıklı okuma, kıraatle okuma, kısa okuma, makamla okuma, mantıki okuma, nağmeli okuma, ön okuma, parmakla okuma, perdeli okuma, ritmik okuma, seçmeli okuma, son okuma, su gibi okuma,

\footnotetext{
Adres $\mid$ Address

İstanbul Medeniyet Üniversitesi, Eğitim Bilimleri Fakültesi, Türkçe ve Sosyal Bilimler Eğitimi Bölümü, Türkce Eğitimi ABD Cevizli Turkish and Social Scinces Education, Turkish Language Teaching Kampüsü, Kartal-İstanbul/TÜRKIYE $\quad$ Education, Cevizli Campus, Kartal-İstanbul /TURKEY e-posta: editor@rumelide.com 1 e-mail: editor@rumelide.com
} 
tekdüze okuma, tekrar tekrar okuma, tempolu okuma, usulüyle okuma, uz okuma, uzun okuma, yavaş okuma, yenibaştan okuma.

\section{Sonuç ve öneriler}

Çalışmada okumanın Türkçedeki yaygın anlam ve kullanımları ele alınmıştır. $\mathrm{Bu}$ anlam ve kullanımların sözlüklere, ansiklopedik eserlere, derleme çalışmalarına, çeşitli kitap ve yayınlara yansıdığı; bağlama göre değişen biçimlerinin olduğu, sözlükteki sıralamasının bağlama göre değiştiği görülmüştür. Söz konusu anlam ve kullanımlar, bu araştırmada verilenlerle sinırlı değildir. Okumanın, bilinen anlamlarının dışında, mecaz olarak, sözlükteki sözcük sayısı kadar anlamı olabilir. Okumak kimine göre kaçış, kimine göre sığınmadır; kimine göre gereksiz bir eylem, kimine göre beynin gidasıdır.

Okumayı her alanla ilişkilendirerek yepyeni tanımlara ulaşmak mümkündür. Teolojiden ekonomiye, psikolojiden politikaya kadar değişik disiplinlerin bilgiye ulaşma, bilgiyi kullanma, analiz ve değerlendirmeleri, teknoloji kullanımları okumanın mecaz anlamlarıyla ifadesini bulabilir.

Okumanın bir okulda, basılı bir kitabı okumak olmadığı, sokaktaki dilden inanç temelli bir söyleme, yorum ve değerlendirmeden kültürel değerlere kadar uzandığı görülmektedir. Bu noktada nihai hedefi anlama olan okumanın; temel ve yan anlamlarını, mecazlı kullanımlarını bilmek, okuma denilen eylemin dildeki etki ve izlerini fark etmek bakımından değer taşımaktadır.

Çalışmada okumanın bağlama göre değişen birçok anlamı belirtilmiştir. Ancak okumayla ilgili olarak günlük hayatta kullanılan ve sözlüklerde yer bulmayan ifadeler de vardır. Örneğin, "satır aralarını okumak" (açıç̧a dile getirilmemiş duygu ve düşünceyi anlamaya çalışmak), "oku baban gibi, eşek olma", "okunmaya değer olmak" vb.

Çalışmada okumanın sözcük, sözcük grubu (birleşik sözcük, deyim, ikileme, atasözü, kalıplaşmış söz, yansıma) ve cümle (bazı atasözlerinde) biçimindeki kullanımları ortaya konulmuştur. Bulgular bölümünde, Türkçedeki okuma ile ilgili birleşik sözcük ve ikilemeler de sıralanmıştır.

Problem durumunda belirtilen ve soru olarak ifade edilen düşünce, çalışmada cevabını bulmuştur. Okuma(k), Türkçede sözlükteki (Güncel Türkçe Sözlük) anlamların (10 farklı anlam) dışında farklı anlamları karşılamakta, bağlama göre birçok farklı anlamda kullanılmaktadır. Sadece argo anlam başlı̆̆ı altında bile okumanın onun üzerinde anlam ve kullanımı olduğu dikkati çeker. Elbette bunlar, okumanın Türkçedeki tüm anlamları değildir. Bu çalışmada tespit edilememiş farklı anlam ve kullanımlar da olabilir. Yeni çalışmalarla bunlar belirlenebilir. Okumanın bu farklı anlamları, okuma eyleminin hayatta ne kadar yer tuttuğunu göstermektedir.

Çalışmadaki düşünceyle benzer doğrultuda, okumanın Türkçedeki farklı anlam ve kullanımlarına, anlamsal boyutlarına değinen kaynaklar da (Göktürk, 1983: 78; Özdemir, 1993: 16-17) vardır. Söz konusu kaynaklar, okumanın özellikle günlük hayattaki birbirinden farklı bazı anlamlarını ele almıştır.

Manguel de, Okumanın Tarihi adlı eserinde okumanın farklı bağlamlarda kullanımını şu şekilde birleştirir:

“Artık var olmayan yıldızların haritasını 'okuyan' bir gökbilimci; bir evin yapılacağı yeri kötü ruhlara karşı korumak için ‘okuyan' Japon mimar; ormanda hayvanların izlerini ‘okuyan' zoolog; kazanacak kâğıdı oynamadan önce ortağının hareketlerini ‘okuyan’ kâğıt oyuncusu; koreografın 
notlarını 'okuyan' dansçı ve dansçının sahnedeki hareketlerini ‘okuyan' izleyici; örülmekte olan bir halının karmaşı desenini 'okuyan' dokumacı; sayfanın üstünde birleştirilmis birden cok nota dizinini 'okuyan' org sanatçısı; bebeğin yüzünde neşe, şaşkınlık ya da korkunun belirtilerini ‘okuyan' ana baba; bir kaplumbağa kabuğundaki eski izleri ‘okuyan' Çinli falcı; gecenin içinde ve çarşafların altında, sevgilinin bedenini görmeden 'okuyan' âşı; ; hastalarına kendi akıl almaz rüyalarını 'okumaya' yardım eden psikolog; elini suya daldırıp da okyanusun akıntılarını 'okuyan' Hawaiili balıkçı; gökyüzünden hava durumunu 'okuyan' çiftçi: Hepsi işaretleri çözebilme ve anlaşılır kılma eylemini kitap okuru ile paylaşıyorlar” (2010: 20).

Çalışmanın, okumanın bağlama göre değişen anlamlarını ortaya koymak yanında bir başka kazanımı da okumanın bilinen tür ve yöntemlerinin dışında okuma türlerinin olduğunu belirtmesidir. Tespit edilen bu okuma türleri, metne bağlı değissebilen stratejiler olarak kullanılabilir.

$\mathrm{Bu}$ çalışma sonucunda okurlara, eğitimcilere, araştırmacılara ve kurumlara şu önerilerde bulunmak mümkündür:

- Okumanın kazandığı yeni anlamlar güncel sözlüklere dâhil edilmelidir.

- Çalışmada ortaya çıkan ve okuma eğitimi kitaplarıyla, öğretim programları ve makalelere yansımamış okuma türleri uygulamaya dayalı, deneysel çalışmalarla araştırılmalıdır.

- Okuma eğitimi derslerinin ilk haftalarında okumanın Türkçede kazandığı anlamlar ve bağlama göre değişen kullanımları ele alınmalı, bu anlamlara ilişkin olarak öğrencilerin örnek cümleler oluşturmaları sağlanmalı ve öğrencilere bu anlam ve kullanımlara ilişkin tarama ve araştırmalar yaptırılmalıdır.

- Okumanın bir başka dildeki anlam ve kullanımları, Türkçedeki anlam ve kullanımlarıyla karşılaştırılmalıdır.

- Okumanın bağlama göre değişen anlamları dışında terimsel anlam ve kullanımları araştırılmalıdır.

- Okumanın bölge ağızlarına yansıyan ancak genel derleme sözlüklerinde yer bulmayan (sosyal medya veya internet sitelerinde görülebilen) anlam ve kullanımları derlenip bir araya getirilmelidir.

- Yeni okuryazarlıklar ve dijital okumalar üzerinde çalışmalar yapılmalıdır.

\section{Kaynakça}

Acaroğlu, M. T. (1992). Türk atasözleri. İstanbul: İletişim.

Aksan, D. (2006). Anlambilim anlambilim konuları ve Türkçenin anlam bilimi. 4. b. Ankara: Engin.

Aksoy, Ö. A. (1971). Atasözleri ve deyimler sözlügü: Atasözleri sözlüğü. Ankara: Ankara Üniversitesi.

Aksoy, Ö. A. (1984). Atasözleri ve deyimler sözlüğü 2 deyimler sözlüğ̈̈. Ankara: TDK Yayınları.

Aksoy, Ö. A. (2004). Bölge ağızlarında atasözleri ve deyimler I-II. Ankara: TDK Yayınları.

Aktunç, H. (1998). Türkçenin büyük argo sözlüğü (tanıklarıyla). İstanbul: Yapı Kredi Yayınları.

Akyalçın, N. (2012). Türkçemizin anlamsal zenginlikleri deyimlerimiz. Ankara: Eğiten Kitap.

Akyalçın, N. (2012). Türkçemizin incileri atasözlerimiz: tanıklı sözlük. Ankara: Eğiten Kitap.

Akyol, H. (2003). Türkçe ilkokuma ve yazma öğretimi. Ankara: Gündüz Eğitim ve Yayıncılık.

\footnotetext{
Adres $\mid$ Address

İstanbul Medeniyet Üniversitesi, Eğitim Bilimleri Fakültesi, Türkçe İstanbul Medeniyet University, Faculty of Education Sciences, ve Sosyal Bilimler Eğitimi Bölümü, Türkce Eğitimi ABD Cevizli Turkish and Social Scinces Education, Turkish Language Teaching Kampüsü, Kartal-İstanbul/TÜRKIYE $\quad$ Education, Cevizli Campus, Kartal-İstanbul /TURKEY e-posta: editor@rumelide.com 1 e-mail: editor@rumelide.com
} 
Akyol, H. (2013). Programa uygun Türkçe öğretim yöntemleri. 6. Baskı. Ankara: Pegem.

Arat, R. R. (1959). Kutadgu Bilig II tercüme. Ankara: Türk Tarih Kurumu Basımevi.

Arat, R. R. (1992). Atabetü'l-Hakayık, Edib Ahmed B. Mahmud Yükneki. Ankara:, Türk Tarih Kurumu.

Arıcı, A. F. (2012). Okuma eğitimi. (Geliştirilmiş 3. Baskı). Ankara Pegem.

Atalay, B. (1970). Abuşka lûgatı veya Çağatay sözlüğü. Ankara: Ayyıldız Matbaası.

Atalay, B. (1986). Divanü Lûgat-it-Türk Tercümesi: I, II, III, IV. Ankara: Türk Tarih Kurumu.

Ayverdi, İ. (2011). Kubbealtı lugatı misalli büyük Türkçe sözlük. İstanbul: Kubbealtı.

Balyemez, S. (2017). "Okul" kelimesi, "ekol" den mi geliyor?. SDÜ Fen-Edebiyat Fakültesi Sosyal Bilimler Dergisi, 40, 115-147.

Battal, A. (1934). İbnü Mühennâ lûgati. İstanbul: Devlet Matbaası.

Bice, H. (1993). Hoca Ahmed Yesevi Divan-ı Hikmet. Ankara: Diyanet Vakfı.

Binbaşı ğlu, C. (1993). Okumanın mekanizması ve okuma aracının bazı nitelikleri. Çağdaş Ĕ̆itim, 18 (193), 15-20.

Bingölçe, F. (2005). Kadın argosu sözlüğü. İstanbul: Metis.

Büyüköztürk, Ş. Çakmak, E. K. Akgün, Ö. E. Karadeniz, Ş. Demirel, F. (2012). Bilimsel Araşttrma Yöntemleri. (11. Baskı). Ankara: Pegem.

Çağatay, S. (1977). Türk lehçeleri örnekleri VIII. yüzyıldan XVIII. yüzyıla kadar yazı dili. 3. Baskı. Ankara: Erol Ofset Matbaacilık.

Çağbayır, Y. (2007). Ötüken Türkçe sözlük: Orhun yazıtlarından günümüze Türkiye Türkçesinin söz varlığı I, II, III, IV. İstanbul: Ötüken.

De Courteille, A. P. (1870). Dictionnaire turk-oriental: destiné principalement à faciliter la lecture des ouvrages de Bâber, d'Aboul-Gâzi et de Mir-Ali-Chir-Nevâï. Imprimé par l'ordre de l'empereur à l'Imprimerie impériale, Paris.

Demirel, Ö. (1999). Türkçe öğretimi. Ankara: Pegem.

Devellioğlu, F. (1980). Türk argosu: inceleme ve sözlük. Ankara: Aydın Kitabevi.

Dilçin, C. (1983). Yeni tarama sözlüğü. Ankara: Türk Dil Kurumu.

Dilçin, C. (1996). Tarama sözlüğ̈̈ V. Cilt. 2. Baskı. Ankara: Türk Dil Kurumu.

Emiroğlu, S. ve Pınar, F. N. (2013). Dinleme becerisinin diğer beceri alanları ile ilişkisi. Turkish Studies, 8 (4), 769-782.

Ergin, M. (2011). Orhun abideleri. 45. Baskı. İstanbul: Boğaziçi.

Ertem, İ. S. (2014). Okuma yazma eğitiminde teknolojinin rolü: gelişmeler, yaklaşımlar ve yeni okuryazarlık. İ. S. Ertem (Ed.). Okuma yazma eğitimi ve teknoloji içinde (s. 51-60). Ankara: Nobel.

Gabain, A. V. (1998). Eski Türkçenin grameri. (Çev. Mehmet Akalın). Ankara: Türk Tarih Kurumu.

Göktürk, A. (1983). Okumasız okuryazarlar. Yazko Edebiyat. 5 (29), 78-80.

Grönbech, K. (1992). Kuman lehçesi sözlüğü. (Çev. Kemal Aytaç). Ankara: Kültür Bakanlığı.

Gülensoy, T. (2007). Türkiye Türkçesindeki Türkçe sözcüklerin köken bilgisi sözlüğü: etimolojik sözlük denemesi I ve II. Ankara: Türk Dil Kurumu.

Güneş, F. (2014). Türkçe öğretimi yaklaşımlar ve modeller. 2. Baskı. Ankara: Pegem.

Harris, A. J. and Sipay, E. R. (1990). How to increase reading ability. (Ninth Edition). New York: Longman. 
Hatiboğlu, V. (1981). Türk dilinde ikileme. 2. Baskı. Ankara: TDK.

http://tdk.gov.tr (en son) erişim tarihi: 28 Ağustos 2020.

https://www.mygaziantep.com erişim tarihi: 20 Ağustos 2020.

İmer, K., Kocaman, A., ve Özsoy, A. S. (2011). Dilbilim sözlüğü. İstanbul: Boğaziçi Üniversitesi.

İzbudak, V. (1936). Atalar sözü. İstanbul: Devlet Basımevi.

Kadri, H. K. (1943). Türk lügati, 3. cilt: Türk dillerinin iştikakı ve edeb̂̂ lûgatleri. İstanbul: Maarif.

Kadri, H. K. (1945). Türk lügati 4. cilt: Türk dillerinin iştikakı ve edebî lûgatleri. İstanbul: Cumhuriyet.

Karatay, H. (2014). Okuma eğitimi. 2. Baskı. Ankara: Pegem.

Korkmaz, Z. (1992). Gramer terimleri sözlüğü. Ankara: TDK.

Manguel, A. (2010). Okumanın tarihi. (çev. Füsun Elioğlu). 5. Baskı. İstanbul: Yapı Kredi.

Mansuroğlu, M. (1947). Anadolu Türkçesi (XIII. asır): Dehhani ve manzumeleri. İstanbul: Bürhaneddin Erenler Matbaası.

MEB (2005). Türkçe dersi öğretim programı ve kılavuzu. Ankara: Devlet Kitapları Basım Müdürlüğü.

Nişanyan, S. (2009). Kelimebaz. İstanbul: Everest.

Ölmez, M. (1991). Altun Yaruk III. Kitap (= 5. Bölüm) (Suvamaprabhasasutra). Ankara: Odak Offset.

Özbay, M. (2011). Anlama teknikleri ı: okuma eğitimi. 2. Baskı. Ankara: Öncü Kitap.

Özdemir, E. (1993). Okuma sanatı: nasıl okumah, neler okumah. İstanbul: İnkılâp.

Razı, S. (2008). Okuma becerisi öğretimi ve değerlendirilmesi. İstanbul: Kriter.

Sami, Ş. (1900). Kâmûs-ı Türkî. İstanbul: İkdam Matbaası.

Saraçbaşı, M. E., ve Minnetoğlu, İ. (1978). Örnekli ve açıklamalı Türkçe atasözleri sözlüğü. İstanbul: Minnetoğlu.

Sevim, O. ve Şeref, İ. (2015). Türkçe öğretmen adaylarının okuma eğitimi dersiyle ilgili görüş ve önerileri. Ekev Akademi Dergisi, 61 (61), 365-378.

Taner, H., And, M. ve Nutku, Ö. (1966). Tiyatro Terimleri Sözlüğü. Ankara: Ankara Üniversitesi.

Tavkul, U. (2000). Karaçay-Malkar Türkçesi Sözlüğü. Ankara: TDK.

Tekin, Ş. (1976). Uygurca Metinler II. Maytrısîmıt Burkancıların Mehdisi Maitreya İle Buluşma Uygurca İptidai Bir Dram (Burkancllı̆ın Vaibhâşika Tarikatine Âit Bir Eserin Uygurcası). Ankara: Sevinç Matbaası.

Tekin, Ș. (2001). Iş̧tikakçını köşesi: Türk dilinde kelimelerin ve eklerin hayatı üzerine denemeler. İstanbul: Simurg.

Timurtaş, F. K. (1972). Yûnus Emre dîvânı, İstanbul: Kervan.

Toparlı, R., Vural, H., Karaatlı, R. (2007). Kipçak Türkçesi sözlüğü. (2. Baskı). Ankara: TDK.

Tuğlacı, P. (1985). Okyanus ansiklopedik sözlük. 8. Baskı. İstanbul: Cem.

Turan, F. (2001). Eski Oğuzca sözlük. Bahşayiş lügati. İstanbul: Bilimsel Akademik.

Yıldırım, A. ve Şimşek, H. (2008). Sosyal bilimlerde nitel araştırma yöntemleri. (7. Baskı). Ankara: Seçkin.

Yıldırım, F. (2006). Adana ve Osmaniye illeri ağızları. Ankara: TDK.

Yıldız, C. (2010). Okuma ve anlama öğretimi. C. Yıldız (Ed.), yeni öğretim programına göre kuramdan uygulamaya türkçe öğretimi içinde (s. 115-152). Ankara: Pegem.

Yudahin, K. K. (1998). Kırgız Sözlüğ̈̈ I-II. (Çev. Abdullah Taymas). Ankara: TDK.

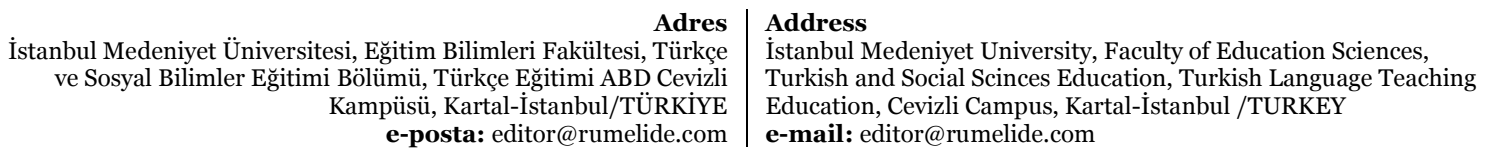


22 / RumeliDE Journal of Language and Literature Studies 2020.21 (December)

A contextual contribution to reading education: use of reading in different meanings in Turkish / S. Emiroğlu (pp. 1-22)

Zal, Ü. (2007). Türk kültüründe "ok"ların taşıdı̆̆ı anlamlar ve "okumak" fiilinin ortaya çıkışı üzerine. Türk Dünyası Araştırmaları, 167, 69-82. 